ACTA UNIVERSITATIS LODZIENSIS

FOLIA LITTERARIA POLONICA 6(36) 2016

http://dx.doi.org/10.18778/1505-9057.36.10

Maciej Tramer*

\title{
Bambo Can Go
}

CASSIUS

Then, Brutus, I have much mistook your passion, By means whereof this breast of mine hath buried

Thoughts of great value, worthy cogitations.

Tell me, good Brutus, can you see your face?

BRUTUS

No, Cassius: for the eye sees not itself, But by reflection, by some other things ${ }^{1}$.

Those who have read William Shakespeare's Julius Caesar will remember a scene from a conversation during which Cassius attempted to convince the impeccable Brutus to join a conspiracy against the tyrant. Everyone remembers, then, what followed, and everyone remembers how it ended. There is no reason whatsoever to use the summary of this storyline to get involved in the glum issue of political intrigue and crime. It is not so much about the story, but the argument used in this dispute; an argument which unveils a rarely noticed and because of this quite sad reality, that the only face that we will not be able to see during out lifetime is our own, and that the only person one can never look in the eye is oneself.

Tuwim knew this mechanism perfectly well - he knew, he saw, and most of all he heard and spoke about it. Shakespeare's authority is necessary here most importantly to make things a bit more difficult. The whole thing could be dealt with without him, with Tuwim alone, for example by quoting the very similar case of Mr. Hilary, who discovers a thing so obvious to the eyes only when he "takes a look in the mirror". The protagonist of a poem about looking for glasses which one had not lost is, however, a humorous and cute character. It would likely be unwise to search for an ontological (or theological, even) motivation in Hilary's

* Dr hab., e-mail: maciej.tramer@us.edu.pl, Theory and Anthropology of Literature Department, University of Silesia in Katowice, 40-032 Katowice, 1 Sejm Śląski square.

${ }^{1}$ W. Shakespeare, Julius Caesar, A. Humphreys (ed.), Oxford University Press, Oxfrod-New York 1998, p. 105. 
desperation, when he shouts: "Scandal! - he screams - Unbelievable!". Let us not risk something this foolish, then. In spite of the suspicion of theft voiced by the clumsy man, a desire to call the police (the state police in later versions), or a plan to demolish his own home, the situation does not seem dangerous at all. One can laugh at Mr. Hilary, one can be moved by him, but it is difficult to take him seriously. No one will believe a jumpy, distracted chap in search for his glasses, and he will not convince anyone to do anything, because neither the poem, nor the character were planning to convince anybody. And this is the entire secret, which does not seem to be a secret at all. An accident is no intrigue. Unlike the conversation of Cassius and Brutus, Tuwim's poem does not force anyone to reflect, it does not unveil anything and convinces no one of anything. It remains see-through, like Hilary's glasses, and as invisible as the eye is to itself. Here is a poem, which seems to be great for analysis, but completely useless when it comes to interpretation.

This is where one would like to say, like Erich Auerbach the author of the most beautiful scholarly book on literature would, that "In that 'real' world, existing for its own purpose, into which we are sucked and in which we are licked, there is nothing more but that world" 2 . In this way, the excellent comparatist commented on a particular style, wonderful, for completely devoid of any further plan, that of Homer. The world of The Odyssey - because this was what the scholar's afterthought referred to - is a reality of "carefree lies", uncomplicated by political intrigue, a world completely uncovered and hiding no secrets. As Auerbach noticed:

the syntactic relationship [...] is completely clear; there is no blurring of borders here. There was also enough time and space for a precise, evenly lit - and with that showing every element - description of gestures, even handshakes; [...]. Clearly described, brightly and evenly lit people - and objects - stand still or move within a clear space; feelings and thoughts are described no less clearly, even in strong affect ${ }^{3}$.

No significant transcription must be done, changing plural form to singular would suffice in order for the most general of Auerbach's comments to be applied to Mr. Hilary's reality. "Homer can be analysed [...], but he cannot be interpreted" - claimed the author of one of the most beautiful essays about literature.

We will not pretend - juxtaposing Homer and Tuwim is an abuse of literature scholarship. Calling on the authority of a literary masterpiece is not supposed to equip a poem which was supposed to be, and is, nothing more than a humorous anecdote with persuasion. The point of this juxtaposition is scholarly mischief,

${ }^{2}$ E. Auerbach, Blizna Odyseusza, in: Mimesis. Rzeczywistość przedstawiona w literaturze Zachodu, translation and introduction by Z. Żabicki, PIW, Warsaw 1968, vol. I, p. 62.

${ }^{3}$ Ibidem, p. 46. 
which will knock the reader out of balance, and thus allow the reader to see, that the transparency of a piece of writing can also constitute its veil.

No great change has to be made, in fact no change at all is needed, it is enough that we accept Homer's story as a bit more subjective - as a declaration made by a specific person, staring into a very specific experience. An evenly lit, uncomplicated and exemplified reality is not the same as simply moving about in a world. This kind of story may be drawn up by a person that is learning a world in order to remember it. If someone determines every aspect, defines the position of each object precisely, meticulously measures out the distance which divides the door to a house from the corner of a street, or precisely counts the number of steps one needs to take in order to pass this distance, then he needs an eye which does not see itself, in order to not see helplessness in such a moving about; in order to not see that only he who is blindfolded tries to remember the world by heart. Surely this is why literary tradition has taken to the image of Homer as a blind man.

In no way do we want to compare Tuwim with Homer; using an indisputable authority to cloud that which is transparent and invisible just seems worthwhile, and more precisely it is about enlightening, explaining that which is (completely) visible. Tuwim's every poem is spoken with a transparent language, which does not mean that it has nothing to tell us. Nor does it mean, that this transparency itself tells us nothing. Maybe only at times it is necessary to, like Taissia Aleksiejewa, travel for 1500 kilometres and read the obviousness of Mr. Hilary's adventures through the glass of Sergey Mikhalkov's (better remembered as the author of the USSR's national anthem) translations. In this translation, Aunt Vala takes Mr. Hilary's place. Like the Polish original, she tunnels through the entire apartment in search for the glasses she has not lost, which in the ends she discovers to be on her head. A rather basic difference pertains to the equipment which she throws around in the meantime, because Aunt Vala is a "poor old lady" who leads a much more modest life than the Pole, she searches through her bed, her furnace, a bucket, dishes, felt shoes and boots. As Aleksiejewa noticed:

It takes Mr. Hilary a long time to find his glasses due to his bourgeoisie extravagance and large amount of things. Aunt Vala's - an old lady's - only problem is a bad memory, dementia. While in Tuwim's variant we have situational humour as well as linguistic play, in Mikhalkov's poem we have a dominance of situational humour ${ }^{4}$.

If this was satire aimed at a city dweller, the Russian translator would have saved the excessive objects, among which the glasses were lost. Mikhalkov's translation does not carry the humour into satire, and rebuilds the scenography on

${ }^{4}$ T. Aleksiejewa, Tuwim w rosyjskich tlumaczeniach S. Michatkowa i A. Achmatowej [a transcript of a lecture given at a conference: Profile Tuwima, University of Warsaw, 9 May 2013]. 
a very basic level in order to translate Tuwim's obviousness, or - more metaphorically - maintain the transparency of Mr. Hilary's and Aunt Vala's glasses. The mirror of a Russian translation was needed in order to see that the mediocrity of the Polish character has a very bourgeois background.

But, let us risk an even deeper analysis of that which is obvious, and like Shakespeare's Cassius, let us risk involving Tuwim in political intrigue. Political intrigue could be heard in a racist comment about John Godson spoken nearly two years ago. Not having noticed that the microphones were on, during a session of one of the Polish Sejm's committees, a representative of a right-wing party bestowed the name of a dark-skinned character he remembered from one of Tuwim's poems upon his political rival ${ }^{5}$. And that is all, let us leave the rest of this issue to those interested, because it is actually too much intrigue and politics for a simple clouding of the clarity of a short story. Especially since the whole Bambo issue was anticipated by Marcin Moskalewicz in a 2005 article, which was an attempt at a postcolonial interpretation of the poem. The issue is actually serious, and - as verified by reality in 2011 - it can even be dangerous. In his article, Moskalewicz wrote:

The consequence of such framing will be a proposed interpretation of the poem, thanks to which, let us hope, it will lose at least a part of its seeming innocence. It will be made readable again, but no longer as a children's story that tries to help two distant worlds approach each other, but as a discursive element of a certain cultural game, which has an entirely opposite role in the system of collective ideas ${ }^{6}$.

Determining that the poem is "seemingly innocent", is a near accusation. But, no less, a valid accusation. On the lips of the racist representative - let us not track this train of thought - Bambo is not meant to be a complement, but a means of discrediting the rival, and is supposed to mean that, just as Tuwim's character did, representative Godson does silly things and "has black skin". And it is this "skin" that appropriates all the silly things done in Tuwim's children's poems. Mr. Hilary does silly things, Mr. Miniscule is not much wiser, Grześ - and this is spoken directly - is a simpleton who "carries a bag of sand", the knight Krzykalski is unwise, Mr. Nightingale is an irresponsible trifler, but Trąbalski the Elephant and Zosia Samosia are no more intelligent; one should add a few scoundrels like

\footnotetext{
${ }^{5}$ See, for example, Suski z PiS o czarnoskórym pośle Godsonie: “Murzynek”, 27.01.2012, http://www. wiadomosci24.pl/artykul/suski_z_pis_o_czarnoskorym_posle_godsonie_murzynek wideo_223662.html [accessed on: 30.11.2013]. See also the interview with MP J.A. Godson: Poset Godson: nie mam nic przeciwko "Murzynkowi Bambo", by P. Brzózka, 30.01.2013, http:// www. dzienniklodzki.pl/artykul/731449, posel-godson-nie-mam-nic-przeciwko-murzynkowibambo, id, t.html [accessed: 30.11.2013].

${ }^{6}$ M. Moskalewicz, "Murzynek Bambo - czarny, wesoly...”. Próba postkolonialnej interpretacji tekstu, "Teksty Drugie" 2005, issue 1-2, p. 260.
} 
Dżońcio, and the golden-feathered hen; and "Grześ the liar" is actually culpably dishonest. Bambo would be similar, but similar he cannot be. "Murzyn" sounds contemptuous, but "murzynek" sounds not only contemptuous, but also disregarding, and his dark skin stigmatizes and rules out any and all silliness. In this day and age, it cannot be otherwise - this is the language we live in, and wrestling with it would be ridiculous.

Moskalewicz's involvement of Bambo in politics was met with a response. Błażej Popławski voiced his approval (clearly accusing the poem, even) of Moskalewicz's concept on the website www.afryka.org? There were, of course - it is impossible to avoid this when proposing a controversial interpretation - protests. A blogger who calls himself Marlow and runs the on-line Galeria Kongo, wrote about this viewpoint in a 2012 article with great disapproval, and even greater disbelief ${ }^{8}$. The high quality of the language he uses proves that the pseudonym was not hiding a random or frustrated commenter on reality, but an author of decent erudition. Either way, the quality of this critique was appreciated by the author of the postcolonial interpretation himself... Half a year after this critical post appeared, Moskalewicz responded:

Dear Marlow, I understand your doubts and teeth-grinding :) Maybe a short addition then - the essay is a sort of intellectual fame, and was written as "overdone" to begin with. This had a goal, namely one of showing how a certain theory "works" (let us add that it was simplified and dogmatized for this purpose) on empirical material coming from a different cultural area than the one it was made for (the original title was longer, and began with "The possibilities and limitations of post-colonial discourse" - it seems like it might have made sense to leave it for the sake of clarity of intention) $)^{9}$.

It is hard not to greet Moskalewicz's admittance of literary abuse, similar to that which is used in this article, with satisfaction. Yet - the same does not have to mean the same thing.

Iwona Gralewicz-Wolny approached Tuwim's poem with a similar assumption to Moskalewicz, however from a somewhat different angle. The way she framed the issue of inappropriateness (I am purposely avoiding the term: political

${ }^{7}$ See B. Popławski, Afryka widziana z peerelu (2): Tuwim, http://afryka.org/afryka/afrykawidziana- z-peerelu--2---tuwim, news/ [accessed on: 3.12.2013]. That speech was given within a series on the perception of Africa in the time of Polish People's Republic ("The first contact with Africa for most Poles in the time of PPR was Murzynek Bambo").

${ }^{8}$ Marlow [pseud.], "Murzynek Bambo - czarny, wesoty...”. Próba postkolonialnej interpretacji tekstu, Marcin Moskalewicz, Galeria Kongo, entry from: 11.04.2012, http://galeriakongo.blogspot. com/2012/04/murzynek-bambo-czarny-wesoy-proba.html [accessed on: 3.12. 2013].

${ }^{9}$ Ibidem. 
incorrectness) is reminiscent of the way Popławski from afryka.org framed it, although she makes her point in a more balanced tone. The poem in Marian Falski's famous Elementarz (ABC-book), and Jerzy Karolak's illustrations from 1957 were read with the awareness of contemporary linguistic sensitivity. Gralewicz-Wolny writes:

The bone of contention is the expression "Murzynek" itself; maybe during the time of the poem's author it was transparent, to us, however, especially to those who are described in this way, it is difficult or even impossible to accept ${ }^{10}$.

And so, the transparent becomes completely murky. Not only due to the writing itself, which - as the author herself notices - "is controversial in a controversial way", but most of all through a basic change in sensitivity. Today, the title character of Tuwim's poem has ossified into a stereotype. Contemporary publications provide much more beneficial reading about Africa, opening the young reader to diversity and forming his or her acceptance of that which is different, according to Gralewicz-Wolny and Popławski: "The newest books on Africa - in my eyes wise and interesting - convince us that the time of "Murzynek Bambo" has happily passed." 11 .

So here we are at a moment where the transparent has become completely murky, and the obvious is not obvious at all. This intransparency can be noticed even in Karolak's 1957 illustrations, where the title's Bambo has no face. In a painting which was included in Elementarz - as Gralewicz-Wolny noted - the character is placed with his back to the reader, and what makes it all the more offensive is the fact that on the next page, a group deemed Our friends is painted facing the reader.

There is no way to disagree, and no way to admit the noble-mindedness of this piece. Especially in the context of a brute comment made by one of the rightwing politicians, which confirms its validity. Due to this - in the most honest and devoid of even the smallest dash of a shadow of irony, I agree.

And more than that even, because the story of Bambo has one more intransparency.

"The wrong poem, the wrong poet, the wrong time" - said Leonard Neuger in December 2012 during a meeting with Polish language students in Katowice. As claimed by the students: "He spoke from the wall", because the conversation happened through the use of an internet connection and a projector. What he did was the most obvious of obvious things: he read the post-colonial interpretation, likely even respected it, then found the poem once more, this time among chil-

${ }^{10}$ I. Gralewicz-Wolny, Pożegnanie Murzynka Bambo [a transcript of a speech given at the conference: Wyczytać świat. Międzykulturowość w literaturze dzieci i młodzieży, University of Silesia in Katowice, 22-23 November 2012 roku].

${ }^{11}$ Ibidem. 
dren's poems and treated it like a poetic plaything from the thirties. Then he laid it in front of the intrigued mob.

In a basic sense nothing happened - the eye did not see itself, but the obvious became obvious. Maybe not as radically as in Auerbach's theory, that "Homer can be analysed [...], but not interpreted", but with an unarticulated reservation - because this was not spoken from a wall by anybody - that the noble interpretation of the poem had happened without analysis. During the talk, an old poetic plaything became a plaything once more and - for the analysis which was being made at the time (and only at that time!) - it was not meant to be anything more. If today one were to take a look at those bits thrown about last year, see if something could be found there; or if that which was completely clear could be seen through even more... Maybe at most one could simply see an out-of-date poem from the angle of the moment when it was created... Let us try.

It is not entirely the case, as authors of the interpretation claim, that Bambo saw the light of day for the first time on the front page of "Literary News" in February of 1935. His first presentation took place one year earlier in The reading book for the second grade of city primary schools developed by Marian Falski ${ }^{12}$. Tuwim had most likely - along with five other poems - written the poem especially for this textbook. On page 15, where the poem was placed, we also find a blackand-white illustration by Kosntanty Sopoćka, where the lone title character, who has a face, curly hair, a large earring in the left ear, a nose, lips, eyes, and a cloth on his hips, stands under a small black-and-white palm tree and sips milk from a coconut. So, we are not exactly dealing with - as Moskalewicz wanted - the ennoblement of a premiering poem by the "eminent 'Literary News" 13 .

Three out of twelve poems written by Tuwim which were placed in the opinion-forming poem weekly were taken straight out of Falski's textbook. In that book, they were not the only poems, but they were the only ones singled out in the table of contents for a text authorization, the rest of the writings and readings remained anonymous. It is not hard to find an answer as to why that happened. In 1934, Tuwim's position as one of the most popular poets was grounded, however his creative work addressed to children did not really exist ${ }^{14}$. Placing entirely new children's poems in this book was an ennoblement for the textbook, but also the discovery of a new Tuwim. This situation, and more precisely this text authorization, provoked a brutal attack by ND (National Democrat) journalists. They were

${ }^{12}$ M. Falski, Czytanka dla II klasy szkót powszechnych miejskich, drawings by K. Mackiewicz, K. Sopoćko, Książnica-Atlas, Lvov 1934, p. 15.

${ }^{13}$ M. Moskalewicz, "Murzynek Bambo - czarny, wesoty...”, p. 260.

${ }^{14}$ Until that time Tuwim had published only two poems for children : Mowa ptaków [The speech of birds] ("W słońcu" 1920, issue 6, p. 81) and Kapuśniaczek [Drizzle] (in: J. Balicki, S. Maykowski, Kraj lat dziecinnych. Pierwszy rok nauki w szkołach średnich ogólnokształcacych, Zakład Narodowy im. Ossolińskich, Warsaw 1926, p. 57). 
not aiming at the controversy of these poem, for it is unlikely that any of them read them, it was about the fact that poems meant to teach the Polish language were written by a Jew. And this seems to be one of the main trends which could have been lost in interpretation. Taking Bambo back to the time of his birth is enough. For what does a happy Murzynek Bambo have to do with the Little Treaty of Versailles from 1919, which regulated the way minority rights were acknowledged? The document was renounced by Poland in the same month of 1934, when the textbook dark-skinned character had his premiere. During this time, pressure which had built up for years began giving results. Its effect was administrative permission for the segregation of students at Polish universities, the so-called "school desk ghetto" and the numerus clausus which meant a limit on Jewish students admitted to universities. In primary and secondary schools, the making of separate institutions for different ethnic groups had been proposed earlier.

Let us leave this glum story of political intrigue and crime; not for the sake of avoidance, but in order to not darken the language, which needs to be transparent. Falski placed Bambo on the fifteenth page of a one-hundred-and-forty page reading book for the second grade of city primary schools, and it constitutes a more familiar environment for the character. For the time during which it was written, the textbook is rather non-political and secular (more so than contemporary textbooks). Easter and Christmas are presented only as holidays with their main attraction being a Christmas tree or decorated eggs Most of the reading materials are stories, which do not persuade, but instead attempt to aid in understanding the surrounding reality, and rarely pertain to anything exotic. There are two which do show something foreign: From the whole world and Foreign rarities, however the conclusion which is drawn from them should surely be that exotic does not always mean exotic ${ }^{15}$. From all the characters of the second grade reading textbook, the "black, happy" character from Tuwim's poem does in fact seem to stand out the most. The diversity of other children is much less.

A second grade student would begin his school adventure by meeting three siblings: Janek, Ala and Zosia: "Ala has dark eyes and dark hair. Janek and Zosia have light hair. And their eyes are blue like the sky" "I . I'm leaving aside the interpretation of the three children's appearance not in order to not abuse it, but because, accordingly with an elementary rule of law honoured by Brutus and Cassius "the obvious requires proof". Everyone who has read the story of Ala, written by Alina Margolis-Edelman for Falski's textbook, knows more or less what I could say ${ }^{17}$. I would even risk stating that the poem's punchline:

\footnotetext{
${ }^{15}$ M. Falski, op. cit., pp. 58-59.

${ }^{16}$ Ibidem, p. 3.

${ }^{17}$ See A. Margolis-Edelman, Ala z "Elementarza", Aneks, London 1994.
} 
A shame that Bambo, cheerful and black,

Does not study with us in our school shack.

Might not have meant a desire to colonise the savage, but a regret that Bambo, who "studied diligently throughout each morning", had to study in a separate school. This, however, would be entangling Tuwim in persuasion, which is not present here.

A shortcut is necessary here - the obvious must remain obvious. No one with at least some reason should expect interpretation from a seven or eight-year-old reader. The text which is addressed to him, with every detail being well lit, did not disguise a second meaning. Everything in this poem was uncovered, everything was clear.

Although Bambo came to be (most probably) as a didactic help, he himself is neither moral (moralizing), nor persuading. Just a wonderful poetic plaything, like most of the (not just children's) poems by Tuwim.

Yet still - the obvious can do everything. Not in a methodical sense, but a very literal sense: everything. Regardless of what group of Poles one might find oneself amongst, every person in this group will know Tuwim's children's poems. Most will know them by heart, and from this majority, surely no one will be able to recall the beginning of this knowledge. We learned (and still learn) to speak with these poems, we learned to read through them, to read and think, etc. And may a great reward go to the one who will solve the mystery today: was it Tuwim who wrote in our language, or are we the ones to speak (read and think) in Tuwim's language? Anyway - why would anyone need the answer? Tuwim's obvious language comes from the fact that Tuwim uncovers that which is not veiled, and what always was (and remains) out in the open; that which is - I would even risk saying - always naked. Language is like a body, meaning that every part of it remains uncovered, or - more precisely - never gets covered - and for this reason it may be particularly sensitive, and particularly at risk for triggers. These where the places which Tuwim's pamphlets, pasquils and philippics touched. The author of the Rhyme Market knew this language "map" very well, and it was thanks to this knowledge that he aimed his rhetorical and satirical blows, always hitting a soft, bare spot on his adversary: it is best to hit the naked face; precisely - the "muzzle"; most precisely - the tongue. Tuwim's aggressive image was completely inauthentic. The poet knew one more obvious truth, that the bare - and therefore sensitive - body part, or language part, is also the most susceptible to positive experiences. In the same precise and obvious language, Tuwim was able to be warm, affectionate and sentimental, inspiring trust and confidence and a promise-giving seducer. He did not always fascinate (he did not have to), but he did always seduce (and that he might have had to). Not many readers will "sublimate" with an author like this, but - let us be honest - who 
can resist him. Obvious? - Obviously. The difference between a poetic boxer and seducer is everything - especially the rhetoric. At times they are similar in their passion, but they are always similar in the lack of mystery (under the condition that it will not be confused with secretiveness and intimacy). And here is where this clarity and obvious obviousness of poetic games comes from, games which found and unveiled the unhidden sensitivity of language without impudence, persuasion, moralizing, or didacticism (as risky as this sounds). In order to feel it, but at the same time in order to learn it by heart. And maybe even so that - why, this could also be the case - in the exchange between reader and poet, social awareness could be revealed. And now it is all clear, what happened... Let us look one more time - the last time - into Bambo's eyes, but only to see our eyes in them. I would like to believe - oh, let it be: I believe! - that Moskalewicz's “"overdone' [...] text" was something more than a joke. And believe this I can, because even if it turned out to be imperfect, or even wrong, it seems fair - just as the equally "overdone" dismay expressed by Popławski, and the reasonable objection raised by Gralewicz-Wolny. For when speaking up about the language, and exposing the language, which can hurt today, all the scholars speak of a linguistic and social awareness. They do not agree to colonize with language, not do they agree to colonize in a language, but they categorically demand the widest and most literally understood communion of laws. In the noble "overdone" interpretation, the only thing that has washed out is the fact that Bambo began speaking in his language amongst less sensitive, gloomy and painful murmurs. So what is worth stressing is the fact that during moments like the year 1934, even neutrality at school is a radical declaration. The sensitivity breeder, which Tuwim was, did all he could at the time - meaning, he did everything. And if today, scholars - more or less correctly - speak up about Bambo's dignity, then it is because today the Other is capable of meaning literally that which it means - for example: a friend. And so there will be no punchline. There will be obviousness. There will only be a rhetorical question about who - not in spite of, but considering the ideas of segregation - let Bambo into school in the thirties, and who in the thirties wrote "our little friend" into their, and in a basic sense all of our reading textbooks? Without persuasion, without force, without unnecessary and boring moralizing didactic... Bambo, written into a reading book eighty years ago, has colonized sensitivity and done that which he was meant to do - counter to the racist phrase: Bambo has done his part, Bambo can go...

\section{Bibliography}

Aleksiejewa Taissia, Tuwim w rosyjskich ttumaczeniach S. Michatkowa i A. Achmatowej [a transcript of a speech given at the conference: Profile Tuwima, University of Warsaw, 9 May 2013].

Auerbach Erich, Mimesis. Rzeczywistość przedstawiona w literaturze Zachodu, translation and introduction by Z. Żabicki, PIW, Warsaw 1968. 
Balicki Juliusz, Maykowski Stanisław, Kraj lat dziecinnych. Pierwszy rok nauki w szkołach średnich ogólnokształcacych, Zakład Narodowy im. Ossolińskich, Warsaw 1926.

Popławski Błażej, Afryka widziana z peerelu (2): Tuwim, http://afryka.org/afryka/afryka-widziana-z-peerelu--2---tuwim, news/ [accessed on: 3.12.2013].

Falski Marian, Czytanka dla II klasy szkót powszechnych miejskich, pic. K. Mackiewicz, K. Sopoćko, Książnica-Atlas, Lvov 1934.

Gralewicz-Wolny Iwona, Pożegnanie Murzynka Bambo [a transcript of a speech given at the conference: Wyczytać świat. Międzykulturowość w literaturze dzieci i młodzieży, University of Silesia in Katowice, 22-23 November 2012].

Margolis-Edelman Alina, Ala z "Elementarza", Aneks, London 1994.

Marlow [pseud.], “Murzynek Bambo - czarny, wesoty...”. Próba postkolonialnej interpretacji tekstu, Marcin Moskalewicz, Galeria Kongo, 11.04.2012, http://galeriakongo.blogspot. com/2012/04/murzynek-bambo-czarny-wesoy-proba.html [accessed on: 3.12. 2013].

Moskalewicz Marcin, “Murzynek Bambo - czarny, wesoły...”. Próba postkolonialnej interpretacji tekstu, "Teksty Drugie" 2005, issues 1-2, pp. 259-270.

Moskalewicz Marcin, [a reply and a turn in a discussion], Galeria Kongo, 7.09.2012, http:/galeriakongo.blogspot.com/2012/04/murzynek-bambo-czarny-wesoy-proba.html" [accessed on: 03.12. 2013].

\section{Maciej Tramer}

\section{Bambo Can Go}

\section{(Summary)}

The author analyses Tuwim's Bambo, the Black Boy and tries to point to a number of interpretative paradoxes that have accumulated around its multiple readings. Particular attention is paid to the racial readings of the poem. What is more, the author discusses a variety of contemporary contexts in which the famous poem functions; these are often politically incorrect readings and interpretations which make no sense of the historical context in which the work was originally written. The article offers a detailed analysis of the origins of the poem and the circumstances in which found its way to the school primer. The poem is seen as expressing the need for accepting otherness and fighting cultural stereotypes.

Keywords: Julian Tuwim, rasism, postcolonialism, stereotype, Tuwim's reception 